\title{
ORIGINAL
}

\section{Synthesis and Hydrolysis of Wax Ester in Mullet}

\author{
Mitsumasa Mankura* and Mitsu Kayama**
}

* Research Laboratories, Ikeda Tohka Industries Co., Ltd. (2-28, Sakurababa-cho, Fukuyama-shi, ₹720)

** Laboratory of Marine Biochemistry, Faculty of Applied Biological Science, Hiroshima University (Shitami, Saijo-cho, Higashihirosima-shi, =724)

The functions of enzymes in WE synthesis by plasma and roe and liver homogenates from the mullet, $M$. cephalus, were studied so as to clarify the metabolism of roe lipid in fish rich in wax esters (WE). The fish examined was $4,130 \mathrm{~g}$ in wet weight with a gonad index of 10.7 . The roe was $17.6 \%$ lipid on a wet weight basis, and the amount of WE in the lipid was about $70 \%$. Carbon numbers ranged from 30 to 34 and the major fatty acids were $16: 1$ and $18: 1$, and the major fatty alcohols, $16: 0$ and $16: 1$.

WE syntheses from $\left[1{ }^{14} \mathrm{C}\right]$ oleic acid and $\left[1-{ }^{14} \mathrm{C}\right]$ oleyl alcohol as well as the hydrolyses of oleyl $\left[1{ }^{14} \mathrm{C}\right]$ oleate occurred to the greatest extent in the roe homogenate. The highest specific and greatest total reducing activity of $\left[1{ }^{14} \mathrm{C}\right]$ oleic acid was also observed in this homogenate. WE synthesizing activity in roe was mainly associated with the $105,000 \times \mathrm{g}$ pellet and supernatant, in which WE formation from $\left[1-^{14} \mathrm{C}\right]$ oleic acid was activated by the addition of ATP, CoA and NADPH. Plasma also possessed activity for WE synthesis from $\left[1{ }^{14} \mathrm{C}\right]$ oleic acid, and its activity increased with cold oleyl alcohol in the reaction mixture.

The enzymes directly related to WE synthesis from fatty acids in the mullet roe may be possibly acyl CoA: alcohol acyltransferase and fatty acid reductase, while those in plasma appear to be lecithin: alcohol acyltransferase instead of lecithin : cholesterol acyltransferase. The high content of WE in roe is possibly due to nutritional requirements and the buoyancy of eggs after hatching. The WE in roe may be one reason for its unique biochemical adaptation.

\section{Introduction}

It is known that triacylglycerols are usually contained in fish as a major reserved lipid, in recent years, however, several papers have given accounts that some marine fishes possess a much amount of wax esters beyond triacylglycerols. According to Kayama ${ }^{1)}$ and Mori et al. ${ }^{21}$, they are lantern fishes, castor oil fishes, Ruvettus pretiosus and Lepidocybium flavobrunneum, Hoplostethus islandicus, Allocyttus verrucosus, coelacanth, Latemeria chalumnae, white barracudina, Paralepis rissoi krфyeri, Lampanyctus regalis, micronectonic fishes Laoemonema morosum, Lottela phycis, Podonema longipes, frill shark, Chlamydoselachus anguineus, stock fish, Merluccius capensis, butterfly fish, Chaetodon trifascialis, mackerel, Scomber japonicus, croaker, Cynoscion nebulosus, Hoplostethus gilchristi, Rexea solandi, and so on. Without deep-sea fishes, midwater animals also contain large amounts of wax esters ${ }^{3 / 7)}$.

Furthermore, we can find some studies ${ }^{8)(14)}$ on wax esters significantly contained in the roe or egg, in which the physiological role or the ecological function is discussed. Mullet, Mugil cephalus, is also well known that the roe has large amounts of wax esters ${ }^{15)-20)}$ and ganglioside ${ }^{21}$. Although many authors reported the distribution and the composition of roe wax esters in fish, no papers except the reports on the metabolism of roe wax esters in gourami, Tricogaster cosby, investigated by Schlenk et al. ${ }^{22) 311}$ inform on the biochemical properties.

To gain some further knowledges on the metabolism of roe lipids in wax ester-rich animal, this article presents the enzymatic properties of wax ester synthesis in vitro by using the plasma and the homogenates of roe and liver from mullet, $M$. cephalus, in addition to the analyses of lipids in roe and other tissues.

\section{Materials and Methods}

\section{$2 \cdot 1$ Chemicals}

$\left[1{ }^{-14} \mathrm{C}\right]$ Oleic acid $(53.8 \mathrm{mCi} / \mathrm{mmol})$ was purchased from New England Nuclear (NEN) through the Nippon Isotope Association. If the purity was less than $99.5 \%$ by determing with a radiochromatogram scanner, it was purified by a 
silicic acid column chromatography ${ }^{32)} \cdot\left[1{ }^{-14} \mathrm{C}\right]$ Oleyl alcohol and oleyl $\left[1{ }^{14} \mathrm{C}\right]$ oleate were prepared as described previously ${ }^{33}$. The specific activities of all labeled compounds resulted are to be same theoretically.

\subsection{Treatment of Fish}

Female mullet, $M$. cephalus, of 4,000 4,200 g body weight (Gonad Index 8.3 11.0) were maintained in a large outdoor tank for several hours before decapitation and excision of tissues. The fishes were caught in the Seto Inland Sea at Jan. 23, 1986. Each tissue was homogenized for $10 \mathrm{~s}$ in an ice-cooled Hiscotron (Nippon Seimitsu Kogyo Co., Ltd. ) with two volumes of $0.05 \mathrm{M}$ $\mathrm{K}$-phosphate buffer ( $\mathrm{pH}$ 7.0) and was centrifuged at $700 \times \mathrm{g}$ for $10 \mathrm{~min}$ to gain the crude supernatant.

\subsection{Tissue Fractionation}

Before killing fish, blood was drawn out as much as possible from dorsal aorta or heart, and citric acid was used as anticoagulant. The following procedures were performed by the method of Griffith et al. ${ }^{311}$ as described previously ${ }^{33)}$. All the processes for preparations were carried out at $0-5^{\circ} \mathrm{C}$ and the following incubations were carried out within $4 \mathrm{~h}$ after killing mullet.

\subsection{Enzyme Assay}

To prepare a substrate emulsified, $5 \mu \mathrm{Ci}$ $(92.9 \mathrm{nmol})$ of each labeled compound dissolved in benzene $(0.5 \mathrm{~mL})$, Triton X-100 (10 mg), and soy bean lecithin $(10.0 \mathrm{mg})$ were added into a Pyrex tube $(10 \mathrm{~mL})$, and were dried under nitrogen stream at $40^{\circ} \mathrm{C}$, which were dispersed in $10 \mathrm{~mL}$ of $5 \%$ bovine serum albumin dissolved in $0.05 \mathrm{M} \mathrm{K}$-phosphate buffer ( $\mathrm{pH} 7.0)$ by sonication for $30 \mathrm{~min}$. Bovine albumin solution used was inactivated by heating at $55^{\circ} \mathrm{C}$ for $1 \mathrm{~h}$ and centrifuged for $5 \mathrm{~min}$ at $3,000 \mathrm{rpm}$ to gain clear supernatant. Non-labeled oleyl alcohol solutions of various concentrations were also prepared as described above. The reactions were allowed to proceed for various periods at $35^{\circ} \mathrm{C}$. The incubation was terminated by the addition of equal volume of methanol.

\subsection{Radioactive Counting}

Lipids from various enzyme mixtures were recovered by the method of Bligh and Dyer ${ }^{34}$ or by the one with minor modification. Lipid separation and radioactive counting were conducted as described elsewhere ${ }^{33}$. The activity for wax ester synthesis is expressed as the ratio of radioactivity incorporated into wax esters (pmol) per mg of protein per $h$. The activity for wax ester hydrolysis is calculated as the ratio of radioactivity released from the substrate, oleyl $\left[1-{ }^{14} \mathrm{C}\right]$ oleate (pmol) per mg of protein per h.

Protein was measured by the method of Lowry et al. ${ }^{35)}$.

\subsection{Lipid Analysis in Various Tissues}

To study the compositions of lipid class and fatty acid in various tissues from mullet, total lipids were extracted by the method of Bligh and $D_{y e r}{ }^{34}$. Lipid class compositions were determined by TLC/FID analyzer. Fatty acid compositions were obtained by GLC of methyl esters using Shimadzu GC-9A instrument (Shimadzu seisakusho Co., Ltd. ) equipped with FID detector and a glass column $(2 \mathrm{~m} \times 3 \mathrm{~mm} \mathrm{i.d}$. $)$ packed with $20 \%$ DEGS on Gas Chrom P. (AW, DMCS, $80 \sim 100$ mesh). Further details are as described previously ${ }^{18)}$.

\subsection{Wax Ester Analysis}

Separation of wax esters from the lipids was accomplished by a silicic acid column chromatography ${ }^{32}$. To analyze the chain length wax esters separated were applied to GLC equipped with FID detector and a glass column $(2 \mathrm{~m} \times$ $3 \mathrm{~mm}$ i.d. ) packed with $1 \% \mathrm{SE}-30$ on chromosorb W (60 $80 \mathrm{mesh})$. Column temperature was kept at $250^{\circ} \mathrm{C}$.

Fatty acid and alcohol compositions of wax esters were gained by GLC of methyl esters and acetates, respectively, according to the method of Takagi et al. ${ }^{36}$.

\section{Results}

\subsection{Lipid Compositions}

The fish examined was a wet weight of $4,130 \mathrm{~g}$ and gonad index ${ }^{18)}$ of 10.7 . The wet weights, lipid contents, and the compositions of lipid class and fatty acid are as shown in Tables-1 and -2 .

Generally speaking, roe, liver, kidney, skin, and muscle had lipid contents of about $15 \%$ or greater on a wet weight basis with the adipose tissue containing over $50 \%$ lipids. The lipid contents of the other tissues examined were lower, ranging from 1 to $10 \%$ wet weight for the spleen, stomach, intestine, and plasma. Of the tissues examined, the roe was an only exception to other patterns of lipid classes, where it was mainly wax esters. The prominent component of 
Table-1 Wet weight, lipid content, and lipid class composition in various tissues from mullet, Mugil cephalus. Lipid extraction and the analysis were performed as described in "Materials and Methods". The body weight of mullet used was $4,130 \mathrm{~g}$.

\begin{tabular}{|c|c|c|c|c|c|c|c|c|c|c|c|}
\hline \multirow{2}{*}{ Tissue } & \multirow{2}{*}{$\begin{array}{c}\text { Tissue } \\
\text { wet weight } \\
(\mathrm{g})\end{array}$} & \multirow{2}{*}{$\begin{array}{l}\text { Lipid } \\
\text { content } \\
\text { (g) }\end{array}$} & \multicolumn{9}{|c|}{ Lipid class in per cent } \\
\hline & & & PL & PG & $\mathrm{FC}$ & FAL & FFA & $\mathrm{TG}$ & WE & $\mathrm{CE}$ & Others \\
\hline Roe & 443.4 & 78.1 & 16.9 & - & 2.1 & 0.3 & - & 11.1 & 68.4 & - & 1.2 \\
\hline Liver & 89.6 & 21.0 & 14.3 & - & - & - & - & 82.9 & - & 2.8 & - \\
\hline Intestine & 44.8 & 4.4 & 23.3 & 1.8 & 15.8 & - & - & 54.2 & - & 2.3 & 2.6 \\
\hline Kidney & 7.4 & 1.3 & 10.9 & 0.3 & 2.0 & - & - & 85.3 & - & 0.7 & 0.8 \\
\hline Spleen & 5.4 & 0.2 & 32.5 & - & 24.7 & - & 13.6 & 20.9 & - & 3.9 & 4.4 \\
\hline Stomach & 52.8 & 0.9 & 38.6 & - & 12.5 & - & - & 46.1 & - & 2.8 & - \\
\hline Gill & 70.3 & 7.3 & 3.1 & - & 1.7 & - & - & 91.9 & - & 3.1 & 0.2 \\
\hline Heart & 6.7 & 1.0 & 14.6 & - & 1.5 & - & - & 74.7 & - & 3.8 & 5.4 \\
\hline Plasma & 45.5 & 0.7 & 67.0 & - & 9.7 & - & - & 13.9 & - & 8.6 & 0.8 \\
\hline Adipose tissue & 29.2 & 16.2 & 4.5 & - & - & - & - & 95.5 & - & - & - \\
\hline Skin & 388.7 & 104.4 & 1.6 & - & 0.7 & - & - & 94.8 & - & 1.4 & 1.5 \\
\hline Muscle + Skelton & $2,787.9$ & 181.8 & 2.8 & - & 0.4 & - & - & 95.2 & - & 0.6 & 1.0 \\
\hline Others & 72.3 & 0.7 & - & - & - & - & - & - & - & - & - \\
\hline Total & $4,044.0$ & 418.8 & & & & & & & & & \\
\hline
\end{tabular}

Abbreviations : PL, polar lipids; PG, partial glycerides; FC, free cholesterol; FAL, free fatty alcohols; FFA, free fatty acids ; TG, triacylglycerols ; WE, wax esters ; CE, cholesterol esters; Others contain diacylglyceryl ethers, fatty aldehydes, and hydrocarbons.

Table-2 Main fatty acid compositions (\%) of various tissue lipids from mullet. GLC conditions are as described in "Materials and Methods".

\begin{tabular}{l|c|c|c|c|c|c|c|c|c|c|c}
\hline \multicolumn{1}{c}{ Component } & $14: 0$ & $16: 0$ & $16: 1$ & $18: 0$ & $18: 1$ & $18: 2$ & $18: 3$ & $20: 5$ & $22: 5$ & $22: 6$ & Others \\
\hline Rissue & 2.4 & 18.9 & 22.4 & 3.9 & 19.7 & 2.6 & 0.8 & 5.8 & 5.6 & 12.0 & 5.9 \\
Roe & 4.7 & 26.8 & 29.0 & 1.7 & 21.4 & 2.7 & 0.7 & 2.1 & 1.7 & 1.9 & 7.3 \\
Intestine & 5.6 & 19.5 & 20.1 & 5.9 & 12.0 & 1.4 & $\mathrm{Tr}$. & 7.5 & 7.1 & 9.9 & 11.0 \\
Kidney & 8.3 & 20.6 & 28.1 & 2.3 & 11.4 & 1.9 & 0.8 & 6.4 & 4.0 & 3.4 & 12.8 \\
Spleen & 3.6 & 23.5 & 16.6 & 8.0 & 14.9 & 0.4 & $\mathrm{Tr}$. & 7.0 & 6.3 & 8.8 & 10.9 \\
Gill & 5.9 & 21.1 & 26.1 & 2.2 & 12.8 & 1.5 & 0.6 & 7.7 & 4.2 & 4.6 & 13.3 \\
Plasma & 1.2 & 29.2 & 14.1 & 9.5 & 24.2 & $\mathrm{Tr}$. & $\mathrm{Tr}$. & 6.0 & 3.4 & 5.0 & 7.4 \\
Skin & 9.8 & 19.7 & 29.6 & 2.2 & 10.5 & 1.9 & 0.8 & 6.2 & 3.0 & 2.8 & 13.5 \\
Muscle+Skelton & 9.7 & 20.3 & 29.6 & 2.2 & 10.6 & 1.9 & 0.8 & 6.2 & 2.8 & 2.5 & 13.4 \\
\hline
\end{tabular}

phospholipids in all tissues tested was phosphatidylcholines.

The predominant wax esters in roe lipids had carbon numbers of 32 and 34 consistent with the major fatty acids being $16: 1$ and $18: 1$, and the major alcohols containing $16: 0$ and $16: 1$ as listed in Tables -3 and -4 .

The composition of either wax esters or the fatty acids and fatty alcohols of the wax esters was similar to previously published analyses ${ }^{18), 19)}$.
Main fatty acids in other tissues examined consisted of $16: 0,16: 1,18: 1,20: 5$, and $22: 6$ mainly.

\subsection{Wax Ester Synthesis and Hydrolysis in Various Tissue Homogenates}

Specific and total activities of wax ester syntheses from $\left[1{ }^{14} \mathrm{C}\right]$ oleyl alcohol and $\left[1-{ }^{14} \mathrm{C}\right]$ oleic acid, and hydrolyses of oleyl $\left[1{ }^{14} \mathrm{C}\right]$ oleate by main tissue homogenates are shown in Fig.-1. Wax ester synthesis from $\left[1-{ }^{14} \mathrm{C}\right]$ oleyl alcohol 
Table-3 Chain-length of wax esters from mullet roe. GLC conditions are given in "Materials and Methods".

\begin{tabular}{c|c}
\hline Carbon number & $\%$ \\
\hline 26 & 0.1 \\
28 & 0.3 \\
29 & Tr. \\
30 & 7.2 \\
31 & 2.4 \\
32 & 47.0 \\
33 & 4.3 \\
34 & 37.8 \\
35 & 0.3 \\
36 & Tr. \\
37 & 0.5 \\
Others & 0.1 \\
\hline Total & 100.0 \\
\hline
\end{tabular}

Table-4 Main fatty alcohol and acid compositions of wax esters from mullet roe. The hydrolysis of wax esters, methylation of fatty acids, and acetylation of fatty alcohlos were conducted as described in "Materials and Methods".

\begin{tabular}{c|c|c}
\hline Component & $\begin{array}{c}\text { Alcohol } \\
(\%)\end{array}$ & $\begin{array}{c}\text { Acid } \\
(\%)\end{array}$ \\
\hline $14: 0$ & 12.1 & 2.1 \\
$16: 0$ & 54.8 & 7.6 \\
$16: 1$ & 15.5 & 39.4 \\
$17: 0$ & 1.2 & 2.8 \\
$17: 1$ & 4.3 & 2.1 \\
$18: 0$ & 6.2 & 2.0 \\
$18: 1$ & 0.7 & 19.2 \\
$18: 2$ & Tr. & 2.7 \\
$18: 3$ & Tr. & 0.3 \\
$20: 5$ & 0.1 & 5.8 \\
$22: 5$ & Tr. & 3.3 \\
$22: 6$ & 0.1 & 6.5 \\
Others & 5.0 & 6.2 \\
\hline Total & 100.0 & 100.0 \\
\hline
\end{tabular}

occurred mainly in roe. Although the total activity in liver, intestine, and gill was lower, the specific one was higher. Surprizingly the wax ester formation was observed in plasma. The radioactivities in fatty acid moiety of wax ester formed from $\left[1-{ }^{14} \mathrm{C}\right]$ oleyl alcohol were traced in all tissues examined.

Wax ester synthesis from $\left[1-{ }^{14} \mathrm{C}\right]$ oleic acid was

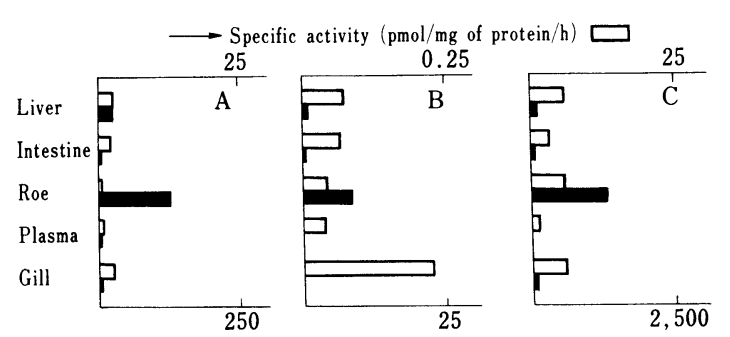

$\longrightarrow \mathrm{nmol} / \mathrm{h}$ calculated for total fraction of each tissue

Fig.-1 Specific and total activities of wax ester syntheses from $\left[1-{ }^{14} \mathrm{C}\right]$ oleyl alcohol $(\mathrm{A})$ and $\left[1{ }^{14} \mathrm{C}\right]$ oleic acid $(\mathrm{B})$, and hydrolyses of oleyl $\left[1^{-14} \mathrm{C}\right]$ oleate $(\mathrm{C})$ by various tissue homogenates from mullet. The assay system consisted of $0.1 \mathrm{~mL}$ of each substrate solution $(0.05 \mu \mathrm{Ci}, 186 \mathrm{nmol})$ and $0.9 \mathrm{~mL}$ of a tissue homogenate in a total volume $1.0 \mathrm{~mL}$. Enzyme employed was the supernatant $(700 \times g$, $10 \mathrm{~min}$ ) obtained from each homogenate with two volumes of $0.05 \mathrm{M} \mathrm{K}$-phosphate buffer (pH 7.0). Incubation was carried out at $35^{\circ} \mathrm{C}$ for $1 \mathrm{~h}$. The specific and total activities are expressed as pmol per mg of protein per $h$ and nmol per $h$ calculated for total fraction of each tissue. Details are described in "Materials and Methods".

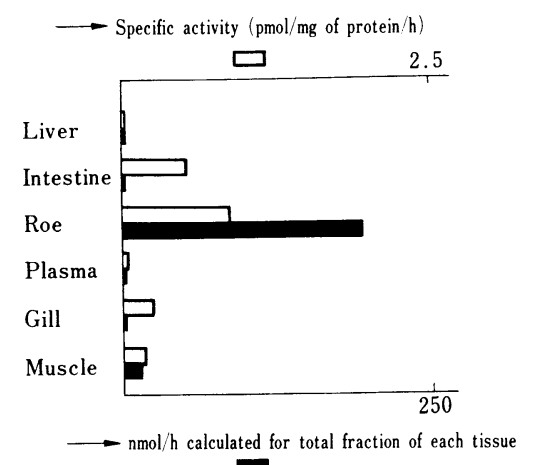

Fig.-2 Reduction of $\left[1-{ }^{14} \mathrm{C}\right]$ oleic acid to fatty alcohol by various tissue homogenates. The assay system consisted of $\left[1-{ }^{14} \mathrm{C}\right]$ oleyl alcohol $(0.05 \mu \mathrm{Ci}, 186 \mathrm{pmol})$, Triton X-100 (0.1 $\mathrm{mg})$, and soy bean lecithin $(0.1 \mathrm{mg})$ which were emulsified in bovine serum albumin $(0.1$ $\mathrm{mL}$ ) dissolved in $0.05 \mathrm{M} \mathrm{K}$-phosphate buffer $(\mathrm{pH} 7.0)$, and $0.9 \mathrm{~mL}$ of each tissue homogenate in total volume $1.0 \mathrm{~mL}$. Incubation was carried out at $35^{\circ} \mathrm{C}$ for $1 \mathrm{~h}$. The activity was expressed as shown in Fig.-1. Details are described in "Materials and Methods".

much lower than the one from $\left[1-{ }^{14} \mathrm{C}\right]$ oleyl alcohol. Although the specific activity in gill was comparatively remarkable, the total one was 
prominent in roe. Other tissue homogenates and plasma had lower activity and were not conspicuous.

The reduction rates of $\left[1-{ }^{14} \mathrm{C}\right]$ oleic acid, which were calculated from radioactivity measurements in the fraction of free fatty alcohols after the reaction was terminated, are shown in Fig.-2. It is clear that both specific and total activities for the reduction in roe were significantly high.

On the other hand, the total hydrolyzing activity of oleyl $\left[1-{ }^{14} \mathrm{C}\right]$ oleate in roe was also the highest among all the tissue homogenates as shown in Fig.-1. However, the specific activities in liver, intestine, and gill were nearly equal to that in roe or a little lower. The hydrolyzing activity was observed in plasma, too.

Although the homogenates of skin and muscle had extremely high activities for wax ester syntheses from both $\left[1-^{14} \mathrm{C}\right]$ oleyl alcohol and $\left[1{ }^{14} \mathrm{C}\right]$ oleic acid as well as those of hydrolysis of oleyl $\left[1-{ }^{14} \mathrm{C}\right]$ oleate, the results are omitted from Table-1.

\subsection{Time Course Changes (Roe)}

As shown in Fig.-3, the formations of wax esters and partial glycerides from $\left[1-{ }^{14} \mathrm{C}\right]$ oleyl alcohol were relatively high, however, the radioactivity incorporations into other lipid clas-
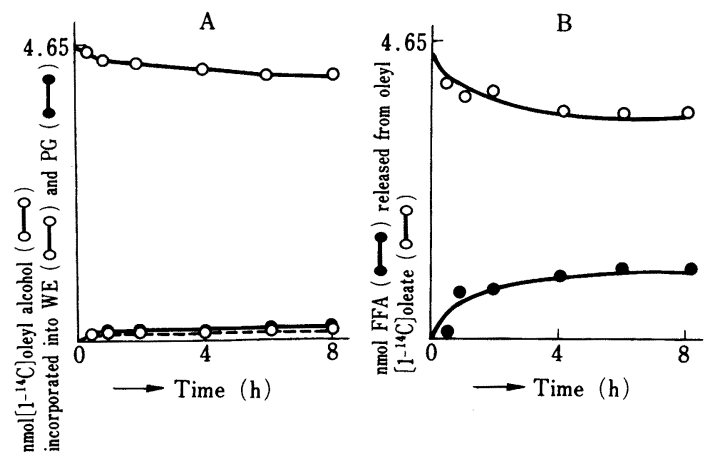

Fig.-3 Time course changes of wax ester syntheses from $\left[1{ }^{14} \mathrm{C}\right]$ oleyl alcohol (A) and hydrolyses of oleyl $\left[1{ }^{14} \mathrm{C}\right]$ oleate $(\mathrm{B})$ by mullet roe homogenate. The assay system consisted of $0.5 \mathrm{~mL}$ of each substrate solution $(0.25 \mu \mathrm{Ci}$, $4.65 \mathrm{pmol}$ ) and $9.5 \mathrm{~mL}$ of tissue homogenate $(25.0 \mathrm{mg}$ of protein $/ \mathrm{mL}$ ) in a final volume $10.0 \mathrm{~mL}$. Incubation was carried out at $35^{\circ} \mathrm{C}$, and $1.0 \mathrm{~mL}$ of the reaction mixture was taken out at various intervals and terminated by the additions of equal volume of methanol. Abbreviations are as shown in Table-1. ses were not noticeable. The conversion (turn over) rates of $\left[1{ }^{14} \mathrm{C}\right]$ oleyl alcohol in the roe homogenate were very low as well as those of $\left[1-{ }^{14} \mathrm{C}\right]$ oleic acid. The reduction or oxidation of these substrates was observed to occur surely. Although the activity was not so high, as results, the reduction or oxidation proceeded the formation of esters and the amounts increased towards the end of incubations.

Oleyl $\left[1-{ }^{14} \mathrm{C}\right]$ oleate was hydrolyzed and the released radioactivities were mainly found in free fatty acids with a little amount of triacylglycerols, polar lipids, partial glycerides, and free fatty alcohols. The conversion rates were much more rapidly than those of $\left[1-{ }^{14} \mathrm{C}\right]$ oleyl alcohol or $\left[1-{ }^{14} \mathrm{C}\right]$ oleic acid.

\subsection{Time Course Changes (Liver)}

Noticeable formation of wax esters from $\left[1-{ }^{14} \mathrm{C}\right]$ oleyl alcohol was observed and the amount increased to the end of incubation as shown in Fig. -4 . $\left[1{ }^{-14} \mathrm{C}\right]$ Oleic acid was also incorporated into other lipid classes such as polar lipids, partial glycerides, and triacylglycerols, but the conversion rate was very low. The oxidation or reduction of these substrates was also observed, and both of the amounts increased to the end of incubation.

On the other hand, the hydrolysis of oleyl $\left[1{ }^{14} \mathrm{C}\right]$ oleate was found to occur lineally for about $4 \mathrm{~h}$ from the start of incubation with the increase of radioactivity in the fraction of free fatty acids. The released free fatty acids pro-

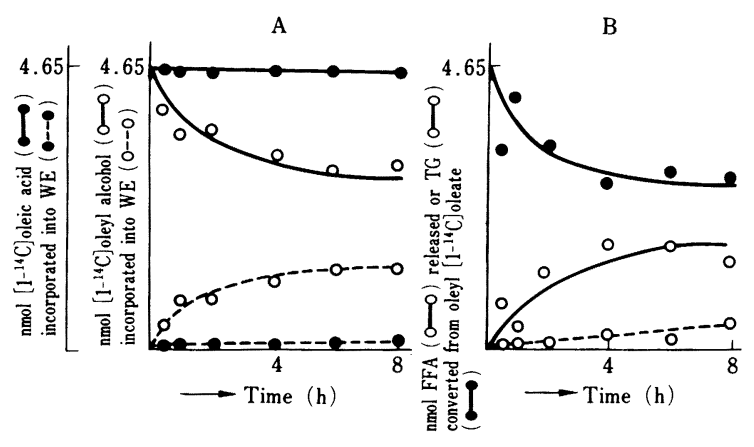

Fig.-4 Time course changes of wax ester syntheses (A) from $\left[1-{ }^{14} \mathrm{C}\right]$ oleyl alcohol and $\left[1-{ }^{14} \mathrm{C}\right]$ oleic acid, and hydrolyses (B) of oleyl $\left[1-{ }^{14} \mathrm{C}\right]$ oleate by mullet liver homogenate. Protein content in assay system was 39.0 $\mathrm{mg} / \mathrm{mL}$. Details are as shown in Fig. -3 . Abbreviations are as shown in Table-1. 

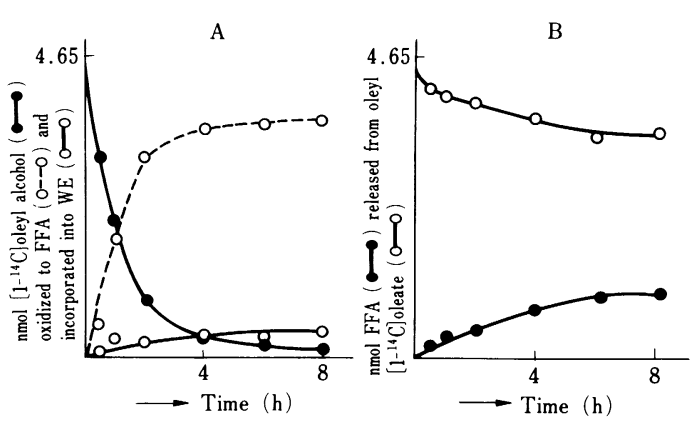

Fig.-5 Time course changes of wax ester syntheses (A) from $\left[1{ }^{-14} \mathrm{C}\right]$ oleyl alcohol and hydrolyses of oleyl $\left[1-{ }^{14} \mathrm{C}\right]$ oleate (B) by mullet plasma. Protein content in assay system was $51.0 \mathrm{mg} / \mathrm{mL}$. Details are as shown in Fig. -3 . Abbreviations are as showm in Table-1.

moted the formation of polar lipids and triacylglycerols, and the amounts increased lineally toward the end of reaction.

\subsection{Time Course Changes (Plasma)}

As shown in Fig. -5 , large amounts of $\left[1-{ }^{14} \mathrm{C}\right]$ oleyl alcohol were rapidly oxidized to free fatty acids, however, some of which were followed to incorporate into polar lipids, partial glycerides, and triacylglycerols mainly with considerable amount of wax esters. The wax ester formation increased lineally to the end of reaction. Some of $\left[1-{ }^{14} \mathrm{C}\right]$ oleic acid was also converted to other lipid classes, especially, polar lipids and triacylglycerols, however, the incorporation into wax esters was observed to be a little.

Hydrolysis of oleyl $\left[1{ }^{14} \mathrm{C}\right]$ oleate was found to be catalyzed by plasma enzyme, too. Released free fatty acids were observed to be incorporated into polar lipids and triacylglycerols with a little amount of partial glycerides.

\subsection{The Effects of Oleyl Alcohol}

As indicated in Fig. -6 , wax ester formations in plasma and liver homogenate were found to be stimulated largely by adding oleyl alcohol at least up to the concentration of $20 \mathrm{mM}$ in the reaction mixture, but in the roe homogenate only a little increase was observed. On the contrary the radioactivity in polar lipids decreased with increasing oleyl alcohol in all cases. Radioactivities in alcohol moieties of wax esters produced by the reaction also decreased with the increasing oleyl alcohol. Generally speaking, without both wax esters and polar lipids, partial glycerides and triacylglycerols were unchangeable major pro-

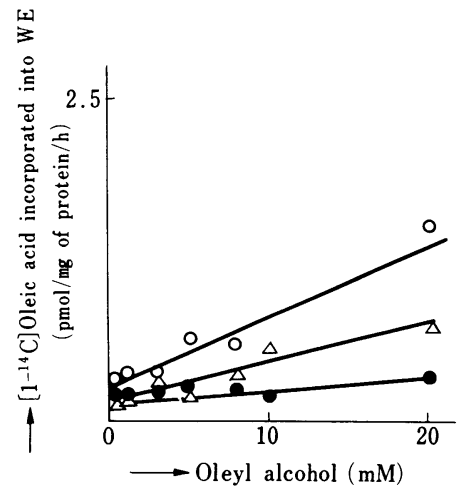

Fig.-6 The effect of oleyl alcohol on wax ester (WE) syntheses from $\left[1-{ }^{14} \mathrm{C}\right]$ oleic acid by mullet plasma $(\Delta-\Delta)$ and the homogenates of roe $(-0)$ and liver $(\bigcirc-\bigcirc)$. The reaction mixture contained substrate solution $(0.1$ $\mathrm{mL})$ containing $\left[1{ }^{14} \mathrm{C}\right]$ oleic acid $(0.05 \mu \mathrm{Ci}$, $930 \mathrm{pmol})$ with non-labeled oleyl alcohol emulsified $(0.4 \mathrm{~mL})$, in which the concentration was prepared and each enzyme solution $(0.5 \mathrm{~mL})$ in a final volume $1.0 \mathrm{~mL}$, and was incubated for $1 \mathrm{~h}$ at $35^{\circ} \mathrm{C}$. Protein concentrations in each assay system were as shown in Fig. $-3,-4$, and -5 .

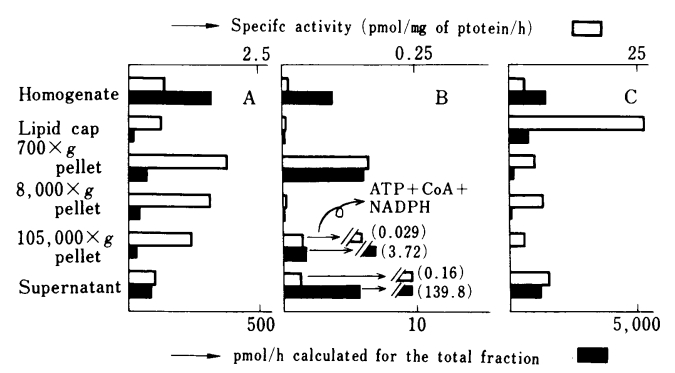

Fig.-7 Specific and total activities of wax ester syntheses from $\left[1{ }^{14} \mathrm{C}\right]$ oleyl alcohol $(\mathrm{A})$ and $\left[1{ }^{14} \mathrm{C}\right]$ oleic acid $(\mathrm{B})$, and hydrolyses of oleyl $\left[1{ }^{14} \mathrm{C}\right]$ oleate $(\mathrm{C})$ by different cell fractions from mullet roe. Reaction mixture contained each substrate solution $(0.1 \mathrm{~mL}, 0.05$ $\mu \mathrm{Ci} / 930 \mathrm{pmol})$ and enzyme solution $(0.9 \mathrm{~mL})$ prepared as described in "Materials and Methods" in which protein concentrations were controlled to be ranged from 10 to 20 $\mathrm{mg} / \mathrm{mL}$, in a final volume $1.0 \mathrm{~mL}$. ATP $(5.0$ $\mu \mathrm{mol}), \mathrm{CoA}(1.0 \mu \mathrm{mol})$, and NADPH $(2.0$ $\mu \mathrm{mol})$ were added to the reaction mixture $(1.0 \mathrm{~mL}$ of $105,000 \times g$ pellet and the supernatant) prepared for wax ester syntheses from $\left[1{ }^{14} \mathrm{C}\right]$ oleic acid. Incubation was carried out for $1 \mathrm{~h}$ at $35^{\circ} \mathrm{C}$. 
ducts of the reaction at any of the concentrations of oleyl alcohol.

\subsection{Cell Fractionations of Roe}

As shown in Fig.-7, the incorporation of $\left[1-{ }^{14} \mathrm{C}\right]$ oleyl alcohol into wax esters was observed in all fractions examined. The specific activities of $8,000 \times g$ pellet (mitochondrial fraction) and $105,000 \times g$ pellet (microsomal fraction) were rather higher than those of 105,000 $\times g$ supernatant. The oxidation of $\left[1^{-14} \mathrm{C}\right]$ oleyl alcohol was also observed to occur in all fractions with the radioactivity incorporations into polar lipids and partial glycerides, in which the specific and total activities were less than those of wax esters, respectively. The radioactivity in acid moiety of wax esters synthesized by all cell fractions was found to be very low or undetermined, and almost all radioactivity was maldistributed in the alcohol moiety.

Although wax esters formed from $\left[1-{ }^{14} \mathrm{C}\right]$ oleic acid by $8,000 \times g$ pellet were very little, 105,000

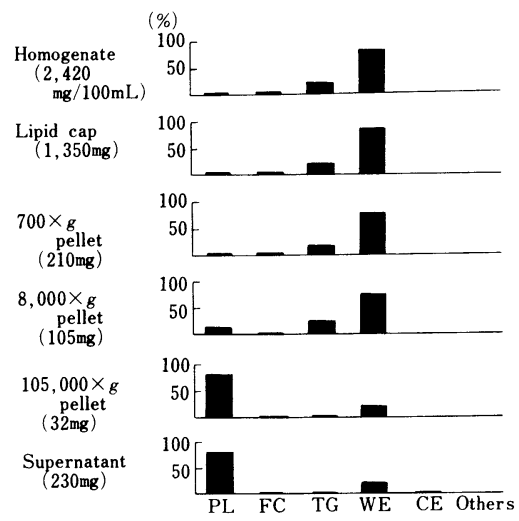

Fig.-8 Lipid class compositions among different cell fractions from mullet roe. Total lipid contents in various fractions are put in parentheses. The recovery was about $79.6 \%$. Abbreviations are as shown in Table-1. $\times g$ pellet and the supernatant were found to synthesize wax esters more efficiently, in addition to the greater reducing activity of the fatty acid to alcohol. $105,000 \times g$ pellet and the supernatant were used to establish the cofactors necessary for wax ester syntheses and resulted that it was stimulated extremely when ATP, CoA, and $\mathrm{NADPH}$ were added to reaction mixtures. NADH was able to replace NADPH partially, but not completely. Although most of the radioactivity in wax esters was distributed in the acid moiety, the amount of alcohol moiety was higher by adding cofactors.

Wax ester hydrolysis also occurred in all fractions employed. The highest specific and total activity was found in $105,000 \times g$ supernatant and lipid cap.

To understand the lipid properties in different cell fractions, the lipid contents and compositions of lipid classes and fatty acids were checked up as shown in Fig. -8 and Table-5. Major lipid component in the fractions of lipid cap, $700 \times g$ pellet, and $8,000 \times g$ pellet was wax esters, which were more than $70 \%$ in total lipids. In these fractions the content of $16: 1$ was up to about $30 \%$ in total fatty acids, however, the content of $22: 6$ was not so noticeable. Whereas, both $105,000 \times g$ pellet and the supernatant contained about $80 \%$ of polar lipids with small amount of wax esters. The main component of polar lipids was phosphatidylcholines when it was examined qualitatively on TLC. In both fractions much lower amount of 16:1 and higher amount of $22: 6$ than those in lipid cap, $700 \times g$ pellet, and $105,000 \times g$ pellet were observed, respectively.

\subsection{Cell Fractionations of Liver}

As shown in Fig. -9 , large amounts of $\left[1-{ }^{14} \mathrm{C}\right]$ oleyl alcohol were incorporated into wax esters in

Table-5 Main fatty acid compositions of the lipids in various cell fractions from mullet roe.

\begin{tabular}{l|c|c|c|c|c|c|c|c|c|c}
\hline \multirow{2}{*}{ Component } & \multicolumn{8}{|c}{ Fatty acid compositions in per cent } \\
\cline { 2 - 10 } Cell fraction & $14: 0$ & $16: 0$ & $16: 1$ & $18: 0$ & $18: 1$ & $18: 2$ & $20: 5$ & $22: 5$ & $22: 6$ & Others \\
\hline Homogenate & 2.5 & 13.0 & 29.3 & 2.3 & 20.4 & 3.1 & 6.3 & 4.2 & 7.5 & 11.4 \\
Lipid cap & 3.1 & 11.6 & 32.6 & 1.4 & 21.3 & 3.3 & 6.0 & 3.5 & 5.9 & 11.3 \\
$700 \times$ g pellet & 2.5 & 13.1 & 30.5 & 2.0 & 20.3 & 3.1 & 6.0 & 4.1 & 6.7 & 11.7 \\
$8,000 \times$ g pellet & 2.8 & 14.2 & 30.5 & 2.1 & 19.9 & 2.3 & 6.1 & 5.7 & 8.4 & 8.0 \\
$105,000 \times$ g pellet & 1.6 & 27.1 & 15.5 & 8.3 & 17.3 & 2.0 & 8.2 & 4.3 & 10.2 & 5.5 \\
$105,000 \times$ g supernatant & 3.9 & 19.7 & 13.0 & 8.9 & 19.8 & 0.2 & 4.3 & 12.6 & 15.0 & 2.6 \\
\hline
\end{tabular}


all cell fractions tested, and the radioactivities in acid moieties of wax esters were traced. The fraction of $105,000 \times g$ supernatant had the greatest total activity of all. Oxidized $\left[1{ }^{-14} \mathrm{C}\right]$ oleyl alcohol was incorporated into polar lipids, partial glycerides, and triacylglycerols mainly besides wax esters.

The incorporations of $\left[1-{ }^{14} \mathrm{C}\right]$ oleic acid into wax esters were also observed in all fractions and the radioactivities in alcohol moieties were very little or undetermined. The highest specific and largest total synthesizing activity were found in the $105,000 \times g$ supernatant, while the reduction was not associated so markedly with any of the fractions. Although a little amount of radioactivity in all fractions was observed in polar lipids, partial glycerides, free fatty alcohols, and triacylglycerols besides wax esters, generally speaking, the conversion rates of $\left[1{ }^{14} \mathrm{C}\right]$ oleic acid to other lipid classes were much lower than those of $\left[1-{ }^{14} \mathrm{C}\right]$ oleyl alcohol. The effects of adding cofactors were similar to the case of roe as mentioned above.

The hydrolysis of oleyl $\left[1-{ }^{14} \mathrm{C}\right]$ oleate was

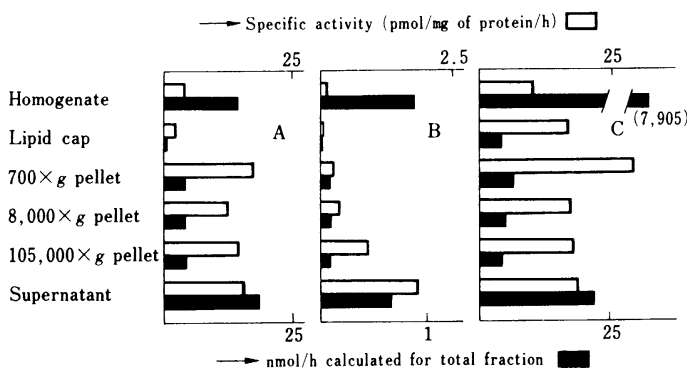

Fig.-9 Specific and total activities of wax ester syntheses from $\left[1{ }^{-14} \mathrm{C}\right]$ oleyl alcohol $(\mathrm{A})$ and $\left[1{ }^{14} \mathrm{C}\right]$ oleic acid $(\mathrm{B})$, and hydrolyses of oleyl $\left[1-{ }^{14} \mathrm{C}\right]$ oleate $(\mathrm{C})$ among different cell fractions from mullet liver. Details are shown in Fig. -7 . observed in all fractions examined. The greatest total hydrolyzing activity was found in the $105,000 \times g$ supernatant.

Lipid contents and the compositions of lipid class and fatty acid in various cell fractions from liver are shown in Fig.-10 and Table-6. Major lipid component in the fractions of lipid cap, 700 $\times g$ pellet, and $8,000 \times g$ pellet was triacylglycerols, which were more than $85 \%$ in total lipids. In those fractions and the $105,000 \times g$ supernatant both $16: 0$ and $16: 1$ were the main components. Whereas, more than $70 \%$ of lipids from $105,000 \times g$ pellet was polar lipids, and most of them were phosphatidylcholines when it was observed qualitatively on TLC. Furthermore, the fatty acid composition in this fraction was characterized by a lower content of $16: 1$ and a

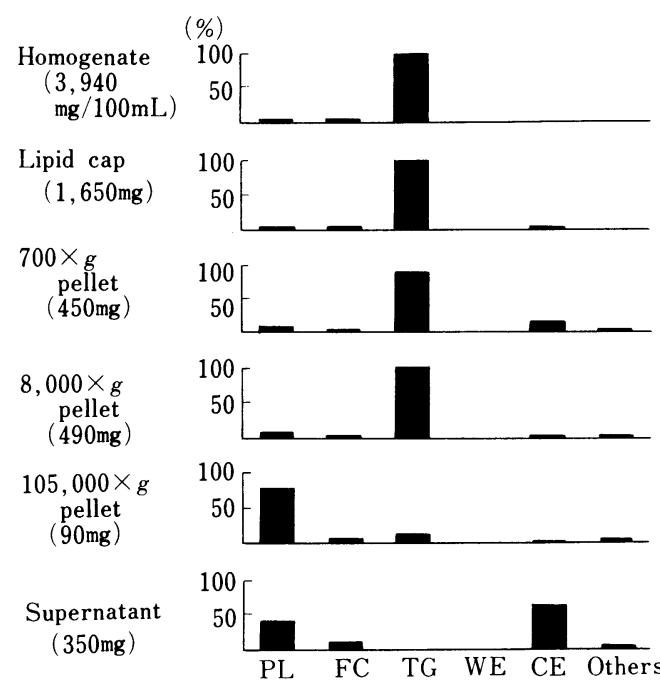

Fig.-10 Lipid class compositions among different cell fractions from mullet liver. Total lipid contents in various fractions are put in parentheses. The recovery was about $76.9 \%$ . Abbreviations are as shown in Table-1.

Table-6 Main fatty acid compositions of the lipids in various cell fractions from mullet liver.

\begin{tabular}{l|r|r|r|r|r|r|r|r|r|r}
\hline \multirow{2}{*}{ Component } & \multicolumn{8}{|c}{ Fatty acid compositions in per cent } \\
\cline { 2 - 11 } Cell fraction & $14: 0$ & $16: 0$ & $16: 1$ & $18: 0$ & $18: 1$ & $18: 2$ & $20: 5$ & $22: 5$ & $22: 6$ & Others \\
\hline Homogenate & 7.9 & 29.2 & 30.2 & 1.3 & 19.1 & 1.1 & 1.7 & 1.4 & 1.4 & 6.7 \\
Lipid cap & 5.4 & 28.1 & 29.2 & 1.4 & 25.2 & 0.8 & 2.4 & 1.8 & 0.2 & 5.5 \\
$700 \times$ g pellet & 6.1 & 27.9 & 27.5 & 1.7 & 19.9 & 1.5 & 2.8 & 1.7 & 1.5 & 9.4 \\
$8,000 \times$ g pellet & 6.3 & 28.2 & 27.3 & 1.8 & 21.3 & 1.3 & 2.2 & 1.9 & 1.9 & 7.8 \\
$105,000 \times g$ pellet & 1.0 & 21.4 & 5.4 & 10.9 & 16.7 & 1.0 & 14.1 & 6.4 & 13.9 & 9.2 \\
$105,000 \times g$ supernatant & 5.9 & 31.5 & 23.4 & 4.0 & 19.6 & 1.0 & 3.6 & 1.8 & 2.7 & 6.5 \\
\hline
\end{tabular}


higher one of $22: 5$ and $22: 6$. In the lipids from $105,000 \times g$ supernatant more than $55 \%$ of cholesterol esters and about $35 \%$ of polar lipids were observed.

\section{Discussion}

Kayama et al. ${ }^{18)}$ described that the maturity of mullet roe can be well expressed by the gonad index (G. I., 100×gonad weight/body weight). There is a relation between G. I. and the wax ester content in roe lipids. The mullet roe examined in the present work had 10.7 of G. I. and $68.4 \%$ of wax esters in total lipids. The results seem to be involved within their insistence.

Each of fish species has the respective compositions of fatty acid and alcohol moieties in roe wax esters ${ }^{8) ~ 14), 18}$. For example, the roe wax esters in both burbot and perch have the major fatty acids being 18: 1 and $22: 6$ with minor amount of $20: 5$ and $16: 1$, and the main alcohols containing 16:0 and 18: ${ }^{8)}$. These differences between these fishes and mullet seem to depend on the environmental factors for the fishes, namely, such as the temperature, depth of living, and food in addition to the disparities of energy metabolisms of the fish egg. However, it is not known why the wax ester in mullet roe contains major fatty acids being $16: 1$ and $18: 1$, and main alcohols holding 16:0 and 16:1.

Although carp hepatopancreas have the highest specific and greatest total synthesizing activity of wax esters in all tissues examined ${ }^{37), 38)}$, in the case of mullet, the roe instead of the liver seems to play an important role on the synthesis and hydrolysis of wax esters, or the reduction of fatty acids.

The free fatty alcohols as a rate-determing factor on wax ester syntheses from free fatty acids are required absolutely. It is natural results that roe homogenate, in which the reduction of fatty acids occurred at the highest rate in all the tissues examined, had the largest total activity for wax ester synthesis from fatty acids or fatty alcohols. The fatty alcohol must be oxidized rapidly to be coupled with non-oxidized oleyl alcohol. When the non-labeled fatty alcohol content in the assay system increased, wax ester synthesis from $\left[1-{ }^{14} \mathrm{C}\right]$ oleic acid in plasma and liver homogenate was promoted more largely than that in roe.
Therefore, the main cause of remarkably high amounts of wax esters in mullet roe is seemed to depend on the reducing activity of fatty acids instead of fatty acyl CoA : fatty alcohol acyltransferase. In that case the remarkable increase of wax ester formation from $\left[1-{ }^{14} \mathrm{C}\right]$ oleic acid by the addition of cofactors in $105,000 \times g$ pellet and the supernatant from roe is able to be explicable, because the addition of ATP and NADPH promotes the reduction of fatty acids ${ }^{39,41}$.

Plasma enzymes also play an important role on wax ester synthesis ${ }^{38,42}$. From the time course study as shown in Fig.-5, it is obvious that the most amount of $\left[1{ }^{-14} \mathrm{C}\right]$ oleyl alcohol is oxidized rapidly to fatty acids and the esterification of added $\left[1-{ }^{14} \mathrm{C}\right]$ oleyl alcohol to the oxidized fatty acids occurs to produce wax esters. It is thought that the low reducing activity of fatty acids in plasma limitted the yield of wax esters because wax ester synthesis from $\left[1{ }^{-14} \mathrm{C}\right]$ oleic acid in plasma was stimulated by adding oleyl alcohol as shown in Fig.-6. Furthermore, it is possible that the circulating lecithin: fatty alcohol acyltransferase (LAAT) instead of fatty acyl CoA : fatty alcohol acyltransferase or lecithin: cholesterol acyltransferase catalyzes the wax ester synthesis in plasma ${ }^{38,42), 43)}$.

Because no wax esters or a small amount of free fatty alcohols were observed in any of tissues without roe, it is suggested that most lipids in foods, in which triacylglycerols, wax esters, phospholipids, and partial glycerides may be contained mainly, are hydrolyzed or oxidized to produce free fatty acids in digestive organs and reesterified to form triacylglycerols and phosholipids generally. These lipids released into plasma will be transported and stored as triacylglycerols and phospholipids. The same mechanism is suggested in the case of $\operatorname{carp}^{38), 431}$.

Generally speaking, both $105,000 \times g$ pellet and the supernatant from mullet roe and liver contain high amount of polar lipids holding a large quantity of polyunsaturated fatty acids such as 20 : $5,22: 5$, and $22: 6$, and lower amount of $16: 1$. Whereas, other cell fractions from roe and liver are rich in wax esters and triacylglycerols, respectively, containing large amount of $16: 1$. The results seem to relate with the differences of specific gravities of wax esters and triacylglycerols, which are 0.8578 and 0.9168 , 
respectively ${ }^{1)}$. It is thought that the possible functions of wax esters containing in fish are generally for buoyancy, permeability control, as energy reserves, and for thermal insulation ${ }^{44)}$ ${ }^{45}$. It is said that the high concentration of wax esters in the egg of drum, Sciaehops ocellata, may be an adaptation for maintaining buoyancy at reduced salinities ${ }^{12}$.

At any rate, the wax esters observed in mullet roe are synthesized from fatty acids and stored in the roe itself, in which the cell fractions of $105,000 \times g$ pellet (microsomal fraction) and the supernatant are largely related to the wax ester formation. And it is thought that the high amount of wax esters in roe is concerned with the nutrition and buoyancy of eggs after hatching out. Therefore, the wax ester present in roe could account for one of a unique biochemical adaptation.

It is noteworthy that the synthesis and hydrolysis of wax esters in muscle and skin from mullet occurred actively. However, the major lipid component in these tissues is triacylglycerols but not wax esters. Moreover, the fatty acid compositions are different from those of roe wax esters. Therefore, it is thought that the roe wax esters are not derived from the muscle or the skin but the roe itself.

\section{(Received Nov. 22, 1988)}

\section{References}

1) M. Kayama, Mar. Sci., 14, 26 (1982).

2) M. Mori, S. Yasuda, and S. Nishimuro, Bull. Jap. Soc. Sci. Fish., 44, 363 (1978).

3) M. Kayama and J. C. Nevenzel, Mar. Biol., 24, 279 (1974).

4) M. Kayama and Y. Ikeda, J. Jpn. Oil Chem. Soc., 24, 435 (1975).

5) M. Kayama and H. Nakagawa, J. Jpn. Oil Chem. Soc., 24, 441 (1975).

6) R. J. Henderson, J. R. Sargent, and S. Falkpetersen, Mar. Biol., 63, 235 (1981).

7) M. A. Neighbors and B. G. Nafpaktitis, Mar. Biol., 66, 207 (1982).

8) J. K. Kaitaranta, J. Sci. Food Agric., 31, 1303 (1980).

9) P. B. Baissac and P. A. Cood, 45 WHA PAP. -Sym. Aquacult. Wastewater, (1980) p. 362.

10) J. K. Kaitaranta, Comp. Biochem. Physiol., 69B, 725 (1981).

11) M. B. Eldridge, J. D. Joseph, K. M. Taberski, and G. T. Seaborn, Lipids, 18, 501 (1983).

12) R. D. Vetter and R. Hodson, Can. J. Fish.
Aquat. Sci., 40, 627 (1983).

13) I. Ahola, J. Kaitaranta, and R. Linko, Pro. Ska. Symp. Lip., 12th (1984) p. 16.

14) D. R. Body, J. Sci. Food Agric., 36, 679 (1985).

15) M. Mori and T. Saito, Bull. Jap. Soc. Sci. Fish., 32, 730 (1966).

16) R. Iyengar and H. Schlenk, Biochemistry, 6, 396 (1967).

17) F. Spener and D. M. Sand, Comp. Biochem. Physiol., 34, 715 (1970).

18) M. Kayama, I. Horii, and Y. Ikeda, J. Jpn. Oil Chem. Soc., 23, 290 (1974).

19) Y. - K. Joh and K-B. Koh, Korean J. Food Sci. Technol., 10, 409 (1978).

20) J. J. Dindo and R. Macgregor III, Trans. Am. Fish. Soc., 110, 403, (1981).

21) Y-T. Li, Y. Harabayashi, R. Degasperi, R. K. Yu, T. Ariga, T. A. Koerner, and S-C. Li, $J$. Biol. Chem., 259, 8980 (1984).

22) D. M. Sand, J. L. Hehl, and H. Schlenk, Biochemistry, 8, 4851 (1969).

23) D. M. Sand and H. Schlenk, Lipids, 4, 303 (1969).

24) D. M. Sand, J. L. Hehl, and H. Schlenk, Lipids, 6, 562 (1971).

25) D. M. Sand, J. L. Hehl, and H. Schlenk, Biochemistry, 10, 2536 (1971).

26) D. M. Sand, J. N. Hehl, and H. Schlenk, Lipids, 6, 562 (1971).

27) D. M. Sand, C. H. Rahn, and H. Schlenk, J. Nutr., 103, 600 (1973).

28) C. H. Rahn, D. M. Sand, and H. Schlenk, J. Nutr., 103, 1441 (1973).

29) C. H. Rahn, D. M. Sand, and H. Schlenk, Comp. Biochem. Physiol., 58B, 17 (1977).

30) K. Thyagarajan, D. M. Sand, H. L. Brockman, and H. Schlenk, Biochim. Biophys. Acta, 575, 318 (1979).

31) T. W. Griffith, D. M. Sand, and H. Schlenk, Biochim. Biophys. Acta, 665, 34 (1981).

32) M. Kayama and Y. Tsuchiya, Tohoku J. Agric. Res., 15, 259 (1965).

33) M. Mankura and M. Kayama, J. Jpn. Oil Chem. Soc., 36, 244 (1988).

34) E. G. Bligh and W. J. Dyer, Can. J. Biochem. Physiol., 37, 911 (1959).

35) O. H. Lowry, N. J. Rosebrough, A. L. Farr, and R. J. Randall, J. Biol. Chem., 193, 265 (1951).

36) T. Takagi, Y. Itabashi, and S. Aso, Lipids, 20, 675 (1985).

37) M. Kayama, M. Mankura, and Y. Ikeda, $J$. Biochem., 85, 1 (1979).

38) M. Mankura, M. Kayama, and N. Iijima, $J$. Jpn. Oil Chem. Soc., 36, 920 (1987).

39) F. Snyder and B. Malone, Biochem. Biophys. Res. Commum., 41, 1382 (1970).

40) M. Kayama and M. Mankura, Bull. Jap. Soc. Sci. Fish., 46, 1501 (1980). 
41) P. E. Kolattukudy and L. Rogers, J. Lipid Res., 27, 404 (1986).

42) M. Mankura and M. Kayama, Bull. Jap. Soc. Sci. Fish., 51, 69 (1985).

43) M. Mankura, N. Iijima, and M. Kayama, Nippon Suisan Gakkaishi, 53, 1221 (1987).

44) J. R. Sargent, R. F. Lee, and J. C. Nevenzel, Marine Waxes. in "Chemistry and Biochemistry of Natural Waxes" (ed. by P. E. Kolattukudy), Elsevier, Amsterdam, (1976) p. 49.

45) M. Kayama, M. Mankura, and Y. Ikeda, J. Jpn. Oil Chem. Soc., 28, 26 (1979).

マボラにおけるワックスエステルの 合成亡分解

万倉三正* · 鹿山 光**

* 池田糖化工業 (株) 研究所 ( 7720 福山市箕沖町 97)

** 広島大学生物生産学部 水族生化学研究室 ( T724 東広島市 西条町下見)

体重約 $4,130 \mathrm{~g}$ (生殖せん指数 10.7) のマボラ, Mugil cephalus, の各組織中の脂質, 特に卵巣脂質に関 し検討すると共に, 血しょうと肝蔵及び卵巣ホモジネー
トによるワックスエステル (WE) の合成と分解をみた。 卵巣脂質含量は全湿重量の $17.6 \%$ で，WE はその内約 70 \%を占めていた。WE のほとんどは炭素鎖長 30 34 で, その脂肪酸部分は主に $16: 1$ 及び $18: 1$ から, アル コール部分は $16: 0$ 及び $16: 1$ から成り立っていた。

$\left[1{ }^{-14} \mathrm{C}\right]$ オイレン酸及び $\left[1{ }^{14} \mathrm{C}\right]$ オレイルアルコール よりの WE 合成又はオレイル $\left[1{ }^{-14} \mathrm{C}\right]$ オリエートの加 水分解は共に卵巣ホモジネート $(\mathrm{RH})$ 中で最も活発で あった。また, $\left[1-{ }^{14} \mathrm{C}\right]$ オレイン酸の還元活性も RH 中 で最大であった。 RH 中の WE 合成醉素は主に, $105,000 \times g$ の沈殿部分（ミクロソーム画分）及びその 上清中に分布しており，ATP, CoA 及び NADPH の添 加により $\left[1{ }^{14} \mathrm{C}\right]$ オレイン酸よりの WE 合成は賦活さ れた。 RH 及び肝蔵ホモジネートと共に血しょうにおい ても $\left[1{ }^{14} \mathrm{C}\right]$ オレイン酸よりの WE 合成は認められ, オレイルアルコール添加により活性はさらに高められ た。

これらの結果から，マボラ卵宩中の脂肪酸よりの WE 合成に直接的に関係する酵素はアシル CoA：アル コールアシルトランスフェラーゼ及び脂肪酸還元酵素で あり，血しょう中のそれはレシチン：アルコールアシル トランスフェラーゼ样醭素であると考えられる。さらに， 卵巣中に多量に存在するWE はふ(孵)化直後の卵の浮 力獲得に関係しており独特な生化学的適応の結果である と推定した。

Łアジア太平洋ココナッッ共同体 (APCC) 専務理事の論評から

油糧種子及び油脂のいくつかの輸出国の政府間グループが集まって行われた最近のセッションの参加者（先進 国之途上国を含む）たちは，いくつかの先進国の保護主義政策の削減に関して，ほとんど前進がみられないこと を强調した。事実，期待に反して先進国の中には高コストの油糧種子に対して補助金を交付したり，従来含まれ なかった高コストの油糧種子を含む価格支持計画の拡大を図るなど刺激策を増やした国もある。多くの先進国に おいて，価格支持水準は世界の市場価格に比べて高い。EEC 諸国において，1988 年の生産大豆はトン当たり 593 ドル，なた权は 492 ドルに価格が支持された。これらの生産物は前年よりも高価格の支持を受けている。

アメリカもまた保護主義政策を続けている。政府の保証は植物油生産者の油脂輸出にまで拡大された。輸出振 興計画 (EEP)のもとに，ある量の植物油の輸出に割増金が与えられている。

いうまでもなく，これらの保護主義政策は発展途上国の輸出業者に大きい損害を与えている。このような価格 では，途上国がこれらの市場で競争することがほとんど不可能になっている。EECもアメリカもやし油の伝統 的市場である。

さらに加えて，補助金に支えられた植物油は，発展途上国の伝統的市場にも侵入しつつある。ココナッツ生産 国のなかの発展途上国は，農民に対してこれほどの大規模の補助を与える立場にない。これに反し政府はそれら に課税を強いられている。

輸出刺激策は当然貿易のゆがみを起こしている。事実彼らは先進国間にさえも貿易援助戦争をひき起こした。

政府間グループ会議の参加者の呼びかけが，EEC とアメリカにできるだけ早く解決を見いだし，補助金によ る輸出競争という現状が両者間で注意されることを望む。 